\title{
Hormonal Control of Liver Regeneration
}

\author{
By SEÁN THROWER and MARGERY G. ORD \\ Department of Biochemistry, University of Oxford, Oxford OX13QY, U.K.
}

(Received 10 May 1974)

\begin{abstract}
Two peaks in cyclic AMP production in rat livers 4 and $12 \mathrm{~h}$ after partial hepatectomy (MacManus et al., 1972) were confirmed and a third peak established at $22 \mathrm{~h}$, which is the peak of DNA synthesis. The increases in cyclic AMP were prevented by $\beta$-adrenergic blocking agents, propranolol and pindolol, without affecting ornithine decarboxylase induction or DNA synthesis. The $\alpha$-blocking agents, phenoxybenzamine and phentolamine, given at the time of partial hepatectomy, delayed the rise in ornithine decarboxylase normally found $4 \mathrm{~h}$ after operation, but did not affect DNA synthesis. If the $\alpha$-blocking agents were given at $9-12 \mathrm{~h}$ or $18 \mathrm{~h}$, the onset of DNA synthesis was delayed. Phenoxybenzamine did not affect the induction of ornithine decarboxylase in intact rat livers by glucagon or growth hormone, but did inhibit induction by dexamethasone. The induction of ornithine decarboxylase produced by dexamethasone was inhibited by $17 \alpha$-hydroxyprogesterone; this compound also blocked the induction of ornithine decarboxylase in livers of partially hepatectomized rats.
\end{abstract}

Hormones of the anterior pituitary, the adrenals and the pancreas are not essential for the process of liver regeneration, but the onset of the regenerative process is facilitated in their presence (Harkness, 1957). The regeneration can be monitored biochemically by measuring the incorporation of $\left[{ }^{3} \mathrm{H}\right]$ thymidine into DNA, which occurs between 18 and $24 \mathrm{~h}$ after partial hepatectomy in normal rats, or by measuring the induction of ornithine decarboxylase (Russell \& Snyder, 1968; Jänne \& Raina, 1968) of which the first peak occurs at about $4 \mathrm{~h}$ after partial hepatectomy. This is followed by a second peak whose timing is dependent on the age and probably the nutritional status of the rat (Hölttä \& Jänne, 1972).

Early in the regeneration there is also an increase in the concentration of cyclic AMP, which is maximal about $4 \mathrm{~h}$ after the operation; this is succeeded by a second peak at about 12h (MacManus et al., 1972, 1973). Because of the involvement of cyclic AMP we decided to look at the effect of agents which interfere with the catecholamine receptors to see if these would affect the regenerative process (Ord \& Stocken, 1972a; Thrower \& Ord, 1972; Thrower et al., 1973).

$\beta$-Blocking agents such as propranolol were ineffective in preventing the first wave of ornithine decarboxylase induction, when given at the time of partial hepatectomy. On the other hand phenoxybenzamine, which blocks $\alpha$-receptors responding primarily to noradrenaline, delayed the appearance of ornithine decarboxylase. If the drug was administered at about $9 \mathrm{~h}$ after partial hepatectomy the first wave of DNA synthesis was inhibited (Thrower et al., 1973). With rats kept under controlled lighting conditions, and the time of access to food carefully restricted, it is possible to obtain animals whose diurnal rhythms are tightly synchronized (Hopkins et al., 1973). By using rats maintained under these conditions before and after partial hepatectomy it was possible to define more precisely the periods of sensitivity to phenoxybenzamine, and to confirm that the effects which are found are probably due to its $\alpha$-adrenergic blocking action since they are are also produced by phentolamine. Additionally, the effects of actinomycin D at different times during the first $24 \mathrm{~h}$ of regeneration were examined.

By studying the effects of these drugs on ornithine decarboxylase induction, on the production of cyclic AMP, and on the factors associated with DNA synthesis, some insight was gained into the role of catecholamines and glucocorticoids in promoting the early stages in compensatory hyperplasia after partial hepatectomy.

\section{Materials and Methods}

\section{Animals}

Male Wistar rats from Scientific Products Ltd. (Charles River U.K. Ltd.), Manston Road, Margate, Kent, U.K., were maintained on a strict feeding and lighting schedule. All rats were fed daily between 12:00 and 15:00h. Some rats had light from 06:00 to 20:00 h and were operated on between 10:00 and 13:00h. Others had light from 15:00 to $05: 00 \mathrm{~h}$ and were operated on between 19:00 and 22:00 h. Rats were used when they weighed 180-200 g. Partial hepatectomies were performed under ether anaesthesia by the procedure of Higgins \& Anderson (1931). 
Adrenalectomized rats were maintained on $0.9 \%$ $(w / v) ~ N a C l$, and used after 4 days.

\section{Administration of drugs and hormones}

Reserpine was injected intraperitoneally in a vehicle containing citric acid, Tween 80 and 2methylpropan-1-ol in water. Other drugs and hormones were injected intraperitoneally as solution or suspension in $0.9 \% \mathrm{NaCl}$ or $60 \%$ (v/v) ethanol. The $0.9 \% \mathrm{NaCl}$ or $60 \%$ ethanol was given similarly to control animals. Growth hormone was obtained from Calbiochem Ltd., London W1H 1AS, U.K.; cyclic AMP, glucagon, dexamethasone and noradrenaline were obtained from Sigma (London) Chemical Co. Ltd., Kingston-upon-Thames, Surrey KT2 7BH, U.K. The phenoxybenzamine was a gift from Smith, Kline and French Ltd., Welwyn Garden City, Herts., U.K. Phentolamine, DL-propranolol and pindolol were gifts from Dr. E. M. Vaughan-Williams, Department of Pharmacology, South Parks Road, Oxford OX1 3QT, U.K.

\section{Assay of ornithine decarboxylase}

A $20 \%(w / v)$ homogenate of rat liver in $25 \mathrm{mM}-$ sodium-potassium phosphate-5 mM-dithiothreitol, was centrifuged at $100000 \mathrm{~g}$ for $1 \mathrm{~h}$ to provide the enzyme extract. The enzyme in the supernatant was assayed (Russell \& Snyder, 1968) in the presence of $5 \mathrm{~mm}$-dithiothreitol; $0.1 \mu \mathrm{mol}$ of pyridoxal phosphate was added/ml of enzyme extract.

The first assay system contained $0.8 \mathrm{ml}$ of buffer [50 mM-Na ${ }_{2} \mathrm{HPO}_{4}-\mathrm{KH}_{2} \mathrm{PO}_{4}$ (pH 7.5)-5 mM-dithiothreitol], $100 \mathrm{nmol}$ of L-ornithine containing $0.1 \mu \mathrm{Ci}$ of DL-[1-14 C]ornithine (1.6-6.7 nmol of DL-ornithine) and $1.0 \mathrm{ml}$ of enzyme. The second assay system had $1.3 \mathrm{ml}$ of buffer $\left[25 \mathrm{mM}-\mathrm{Na}_{2} \mathrm{HPO}_{4}-\mathrm{KH}_{2} \mathrm{PO}_{4}(\mathrm{pH} 7.5)\right.$ $5 \mathrm{mM}$-dithiothreitol], $100 \mathrm{nmol}$ of L-ornithine containing $0.1 \mu \mathrm{Ci}$ of $\mathrm{DL}-\left[1{ }^{14} \mathrm{C}\right]$ ornithine and $0.5 \mathrm{ml}$ of enzyme. After a $20 \mathrm{~min}$ incubation at $37^{\circ} \mathrm{C}$ the reaction was stopped by the addition of $0.2 \mathrm{ml}$ of $2.5 \mathrm{M}-\mathrm{H}_{2} \mathrm{SO}_{4}$. The ${ }^{14} \mathrm{CO}_{2}$ produced was trapped in Hyamine $10-\mathrm{X}$ $(0.1 \mathrm{ml}$ of $1 \mathrm{M}$-Hyamine $10-\mathrm{X}$ in methanol). After a further $30 \mathrm{~min}$ at $37^{\circ} \mathrm{C}$ the vial containing the Hyamine 10-X was removed and dropped into $10 \mathrm{ml}$ of toluene-Triton X-100-butyl-PBD [5-(4-biphenylyl)2-(4-t-butylphenyl)-1-oxa-3,4-diazole] scintillant to which $1 \mathrm{ml}$ of $1 \mathrm{M}-\mathrm{HCl}$ was added before counting for radioactivity. The first procedure was used only for the first two sections of Table 3, where values for partially hepatectomized rats at 3.2 and $4 \mathrm{~h}$ after operation were 161.4 and 157.8 c.p.m./20 min per $\mathrm{mg}$ of protein. Thereafter the second assay, with the decreased amount of enzyme, was followed; this gave 335 c.p.m./20min per $\mathrm{mg}$ of protein for partially hepatectomized rats at $3 \mathrm{~h}$ after the operation (see below).

\section{Assay of cyclic AMP}

Rats were anaesthetized with ether, and the large right-hand side liver lobe remaining after $70 \%$ hepatectomy was removed and freeze-clamped. The lobe was weighed, and homogenized in $5 \%(w / v)$ trichloroacetic acid; the supernatant was frozen and stored at $-20^{\circ} \mathrm{C}$ until assayed.

Cyclic AMP was assayed essentially by the method of Cooper et al. (1972). The assay was calibrated in the presence of trichloroacetic acid. Samples were purified to check the authenticity of the cyclic AMP; the measured content of cyclic AMP in the samples was unchanged after ether extraction of the trichloroacetic acid and after purification on Dowex 50 (G. Schultz, E. Böhme \& J. G. Hardman, personal communication).

\section{Preparation of histone fractions}

Nuclei were isolated from rat liver by the Cemulsol detergent method (Dabeva \& Tsanev, 1966), and washed in $10 \mathrm{~mm}$-Tris-HCl-5 mM- $\mathrm{MgCl}_{2}$, pH7.2. Histone $\mathrm{F} 1$ was extracted with $5 \%(\mathrm{w} / \mathrm{v})$ $\mathrm{HClO}_{4}$ and the remaining histones were extracted with $250 \mathrm{~mm}-\mathrm{HCl}$. Both fractions were precipitated with $25 \%(w / v)$ trichloroacetic acid and redissolved in water before use.

\section{Protein determination}

Protein was measured by the method of Lowry et al. (1951) with bovine serum albumin [Sigma (London) Chemical Co. Ltd.] as standard.

\section{Incorporation of $\left[{ }^{3} \mathrm{H}\right]$ thymidine into $\mathrm{DNA}$}

Rats were given an intraperitoneal injection of 15 or $20 \mu \mathrm{Ci}$ of $\left[6^{3} \mathrm{H}\right]$ thymidine $1 \mathrm{~h}$ before death. They were killed by cervical dislocation, blood was collected and the small left-hand side lobe of the liver was removed into $5 \%(\mathrm{w} / \mathrm{v})$ trichloroacetic acid, homogenized, washed three times with ethanol, washed twice at $70^{\circ} \mathrm{C}$ with ethanol-ether $(3: 1, v / v)$ and dried. DNA was extracted in $5 \%(\mathrm{w} / \mathrm{v})$ trichloroacetic acid at $90^{\circ} \mathrm{C}$ for $20 \mathrm{~min}$. The deoxyribose was determined by the method of Burton (1956) and the radioactivity was counted. Blood was deproteinized in $5 \%(w / v)$ trichloroacetic acid and the ${ }^{3} \mathrm{H}$ content was measured.

\section{Radiochemicals}

All radiochemicals were obtained from The Radiochemical Centre, Amersham, Bucks., U.K. The specific radioactivities were: $\left[6-{ }^{3} \mathrm{H}\right]$ thymidine, $30 \mathrm{Ci} /$ mmol; L-[4,5(n)- $\left.{ }^{3} \mathrm{H}\right] l y s i n e, ~ 8.7 \mathrm{Ci} / \mathrm{mmol}$; $\mathrm{DL}-\left[1{ }^{14} \mathrm{C}\right]-$ ornithine, $15-61 \mathrm{mCi} / \mathrm{mmol}$; [ $\left.{ }^{32} \mathrm{P}\right]$ phosphate, 60 $120 \mathrm{Ci} / \mu \mathrm{g}$ of $\mathrm{P}$; cyclic $\left[8-{ }^{3} \mathrm{H}\right] \mathrm{AMP}, 30 \mathrm{Ci} / \mathrm{mmol}$. 


\section{Radioactivity determinations}

Millipore filters used in the measurements of cyclic AMP were dissolved in $1 \mathrm{ml}$ of 2-methoxyethanol and counted in $10 \mathrm{ml}$ of toluene-2-methoxyethanol-butylPBD scintillant [200 $\mathrm{ml}$ of 2-methoxyethanol+ $800 \mathrm{ml}$ of $0.5 \%(\mathrm{w} / \mathrm{v})$ butyl-PBD in toluene]. Other ${ }^{3} \mathrm{H}$ radioactivity was counted in dioxan scintillant. The efficiency was about $30 \% \cdot{ }^{14} \mathrm{C}$ radioactivity was counted in toluene-Triton X-100-butyl-PBD [300 ml of Triton X-100+700 ml of $0.5 \%$ (w/v) butyl-PBD in toluene] with an efficiency of about $85 \%$. All counts were recorded to give an accuracy of $\pm 2 \%$.

\section{Results}

Sensitivity of DNA synthesis to adrenergic blocking agents and actinomycin $D$

Our earlier experiments had shown that although the induction of ornithine decarboxylase was delayed by giving phenoxybenzamine to partially hepatectomized rats at the time of operation, this did not affect $\left[{ }^{3} \mathrm{H}\right]$ thymidine incorporation into DNA at $22 \mathrm{~h}$ (Thrower et al., 1973). When the drug was given at 9-12h, however, DNA synthesis at $22 \mathrm{~h}$ was diminished, although it was unaffected if the phenoxy- benzamine was administered at $21 \mathrm{~h}$. More careful examination of the timing of the sensitivity of DNA synthesis at $22 \mathrm{~h}$ to phenoxybenzamine administration indicated the precision of the response to the drug (Fig. 1). At 5-8 h after partial hepatectomy the drug had no effect on DNA synthesis at $22 \mathrm{~h}$, but it was markedly inhibitory at 9-12 h, being most effective if given at $12 \mathrm{~h}$. Administration at $18 \mathrm{~h}$ also decreased $\left[{ }^{3} \mathrm{H}\right]$ thymidine incorporation into DNA at $22 \mathrm{~h}$.

Phenoxybenzamine is primarily an $\alpha$-adrenergic blocking drug, but doubts have been raised about the specificity of its action (Furchgott, 1972). Therefore we repeated the experiments with phentolamine, which is a different class of $\alpha$-adrenergic blocking agent (Fig. 1). The results confirmed the existence of the two points of sensitivity of DNA synthesis to $\alpha$-adrenergic blockage.

Fujioka et al. (1963) studied the effect of repetitive low doses of actinomycin $\mathrm{D}$ given at early times in regeneration and showed that these delayed DNA synthesis. Therefore we examined the effect on the peak of DNA synthesis at $22 \mathrm{~h}$ of a single low dose of actinomycin $\mathrm{D}(35 \mu \mathrm{g} / \mathrm{kg})$ given at various times during regeneration. The pattern of response to actinomycin was more complex than that to the $\alpha$-adrenergic

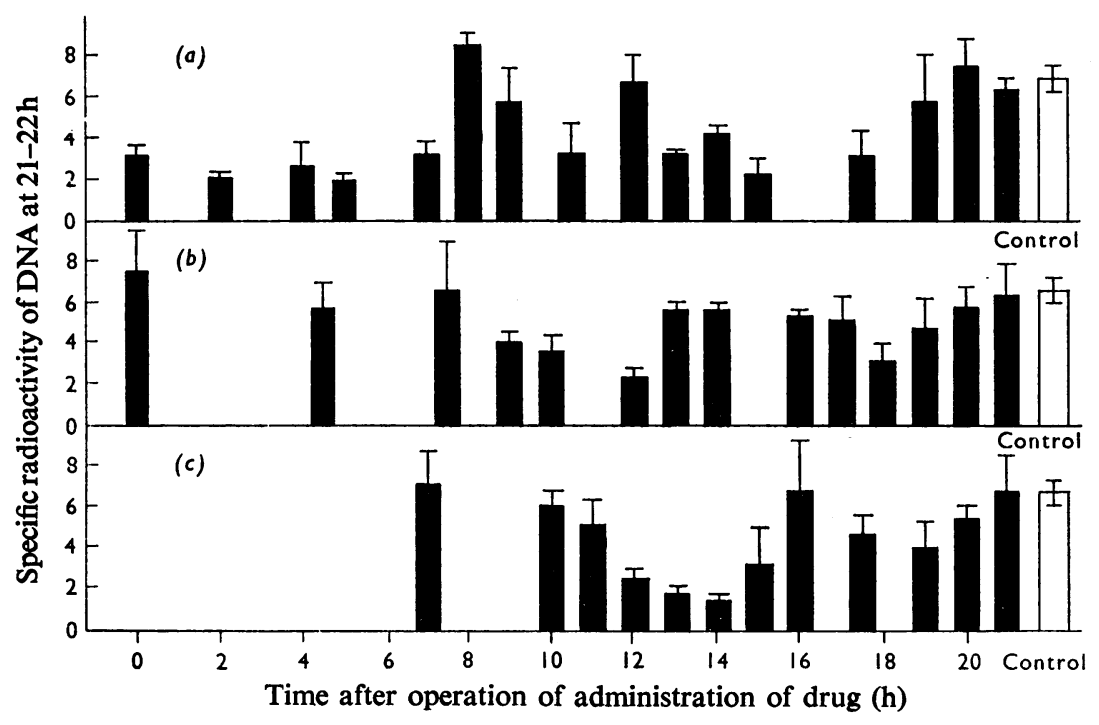

Fig. 1. Effects on the peak of DNA synthesis 21-22h after partial hepatectomy of the time of administration of $\alpha$-adrenergic blocking agents and actinomycin $D$

Single doses of actinomycin D (35 $\mathrm{g} / \mathrm{kg})$, phenoxybenzamine $(5 \mathrm{mg} / \mathrm{kg})$ and phentolamine $(10 \mathrm{mg} / \mathrm{kg}) \mathrm{were}$ given intraperitoneally at the indicated times after partial hepatectomy, and the incorporation of $\left[{ }^{3} \mathrm{H}\right]$ thymidine into DNA at $21-22 \mathrm{~h}$ was measured as described in the Materials and Methods section. Thymidine incorporation is expressed as $10^{2} \times \mathrm{c} . \mathrm{p} . \mathrm{m}$./mg of DNA relative to the ${ }^{3} \mathrm{H} \mathrm{c.p.m./ml} \mathrm{of} \mathrm{blood.} \mathrm{The} \mathrm{S.E.M.} \mathrm{for} \mathrm{each} \mathrm{point} \mathrm{is} \mathrm{indicated} \mathrm{by} \mathrm{the} \mathrm{bar.} \mathrm{All} \mathrm{the} \mathrm{rats} \mathrm{were} \mathrm{kept} \mathrm{in} \mathrm{light}$ from 06:00 to 20:00h and with food available ad lib. Groups of three to five rats were used at each time-point and experiments at $10-13 \mathrm{~h}$ and $17-20 \mathrm{~h}$ after partial hepatectomy were performed at least twice with each drug. (a) Actinomycin D; (b) phenoxybenzamine; (c) phentolamine. 


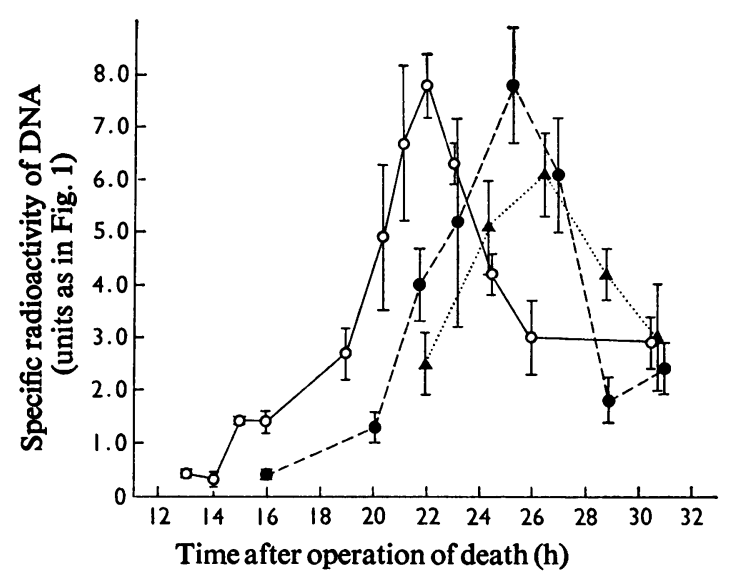

Fig. 2. Time-course of DNA synthesis in regenerating liver after administration of actinomycin D or phenoxybenzamine 9-11 $h$ after operation

Partially hepatectomized rats were given a single dose of phenoxybenzamine $(5 \mathrm{mg} / \mathrm{kg}$ body wt.) at $9 \mathrm{~h}$ after operation or actinomycin $\mathrm{D}(35 \mu \mathrm{g} / \mathrm{kg}$ body wt.) at $11 \mathrm{~h}$ after operation, and the incorporation of $\left[{ }^{3} \mathrm{H}\right]$ thymidine into DNA was determined at times between 12 and $30 \mathrm{~h}$ after operation as described in the Materials and Methods section. Groups of three to five rats were used for each time point. $O$, Control; $\bigcirc$, phenoxybenzamine-treated; $\Delta$, actinomycin D-treated. blocking agents, but the two points of sensitivity at $10.5 \mathrm{~h}$ and at $15-17 \mathrm{~h}$ resembled and preceded the time of maximal sensitivity to phenoxybenzamine and phentolamine. The effect of both actinomycin $D$ and phenoxybenzamine, when given at 9-11 h (Fig. 2), was to delay DNA synthesis. Like phenoxybenzamine, actinomycin $D$ given at $21 \mathrm{~h}$ did not inhibit DNA synthesis at $22 \mathrm{~h}$ (Fig. 1).

Our earlier experiments have suggested that the effects of phenoxybenzamine at 9-12h were due to interference in the process of enzyme induction, as was its action at the time of operation. Nuclear histone F1 phosphokinase induction (Thrower et al., 1973) and thymidine phosphorylation (Ord \& Stocken, 1974) were delayed so that the activities of the enzymes at $18 \mathrm{~h}$ after partial hepatectomy were low. $\left[{ }^{32} \mathrm{P}\right] \mathrm{Phosphate}$ incorporation into histone $\mathrm{F} 1$ was similarly delayed (Table $1 a$ ), being markedly inhibited at $18.5 \mathrm{~h}$. The same pattern of inhibition was observed for histone F1 biosynthesis, measured as $\left[{ }^{3} \mathrm{H}\right]$ lysine incorporation, and for DNA synthesis, measured as [ $\left.{ }^{32} \mathrm{P}\right]$ phosphate incorporation (Table $1 a)$. Table $1(b)$ shows that phenoxybenzamine inhibition was not due to inhibition of general protein synthesis. Actinomycin D given at $11 \mathrm{~h}$ also inhibited both DNA synthesis and histone F1 biosynthesis at 21.5 h (Table 1c).

We also examined the effect of phenoxybenzamine given at the later blocking time of $18 \mathrm{~h}$ (Table $1 d$ ): in this case the inhibition of DNA synthesis at $22 \mathrm{~h}$ was

Table 1. Effect of phenoxybenzamine given at 9 and $18 \mathrm{~h}$, and of actinomycin $D$ given at $11 \mathrm{~h}$, after partial hepatectomy on protein and DNA synthesis in regenerating rat liver

Actinomycin $\mathrm{D}(35 \mu \mathrm{g} / \mathrm{kg}$ body wt.) was administered intraperitoneally at $11 \mathrm{~h}(c)$. Phenoxybenzamine $(5 \mathrm{mg} / \mathrm{kg}$ body wt.) was given intraperitoneally at $9 \mathrm{~h}(a$ and $b)$ or $18 \mathrm{~h}(d)$. Where used, $\left[{ }^{3} \mathrm{H}\right]$ lysine $(10 \mu \mathrm{Ci} / 200 \mathrm{~g}$ rat $)$ and $\left[{ }^{3} \mathrm{H}\right]$ thymidine $(15 \mu \mathrm{Ci} / 200 \mathrm{~g}$ rat $)$ were given $1 \mathrm{~h}$ before death and [ $\left.{ }^{32} \mathrm{P}\right] \mathrm{phosphate}$ was given $1.5 \mathrm{~h}$ before death. Extraction of DNA, histone and total protein was as described in the Materials and Methods section. In Expt. (a), $\left.{ }^{32} \mathrm{P}\right]$ phosphate incorporation into DNA and histone is given as $10^{6} \times$ c.p.m./ $\mu \mathrm{g}$ of DNA or $10^{6} \times$ c.p.m. $/ \mu \mathrm{g}$ of F1 histone relative to the acid-soluble ${ }^{32} \mathrm{P} \mathrm{c.p.m} . / \mathrm{g}$ of liver; $\left[{ }^{3} \mathrm{H}\right]$ lysine incorporation into histone is given as $10^{3} \times$ c.p.m./ $\mu \mathrm{g}$ of $\mathrm{F} 1$ histone relative to the acid-soluble ${ }^{3} \mathrm{H}$ c.p.m./g of liver. In Expts. $(b)-(d),{ }^{3} \mathrm{H}$ incorporation is expressed as $\left[{ }^{3} \mathrm{H}\right]$ thymidine c.p.m./ $\mu \mathrm{g}$ of DNA or $\left[{ }^{3} \mathrm{H}\right] l y s i n e$ c.p.m./ $\mu \mathrm{g}$ of protein. The values given are means \pm S.E.M., with the numbers of experiments in parentheses.

(a) Control

Treatment

+Phenoxybenzamine

(b) Control

+Phenoxybenzamine

(c) Control

+Actinomycin D

(d) Control

+Phenoxybenzamine
Time of death

(h after operation)

18.5

21.5

18.5

21.5

18.5

21.5

18.5

21.5

22.0

22.0

22.0

22.0
DNA
synthesis

$5.0 \pm 0.57$ (3)

$5.2 \pm 0.99(3)$

$1.6 \pm 0.42(3)$

$3.7 \pm 0.17$ (4)

$2.0 \pm 0.44$ (6)

$2.7 \pm 0.22(6)$

$0.8 \pm 0.18$ (6)

$1.1 \pm 0.50$ (6)

$2.7 \pm 0.61$ (3)

$2.2 \pm 0.29$ (4)

$2.7 \pm 0.21$ (4)

$1.4 \pm 0.42$ (3)
F1 histone synthesis

$72 \pm 2.4$ (3)

$61,34(2)$

$18 \pm 3.2$ (3)

$37 \pm 4.1$ (4)

$2.2 \pm 0.27$ (6)

$2.4 \pm 0.28$ (6)

$1.2 \pm 0.22(6)$

$1.7 \pm 0.28$ (6)

$3.0 \pm 0.53(3)$

$1.6 \pm 0.20(4)$

$3.4 \pm 0.60$ (4)

$3.7 \pm 0.20$ (3)
F1 histone phosphorylation

$0.71 \pm 0.084$ (3)

$0.55 \pm 0.054$ (3)

$0.14 \pm 0.038$ (3)

$0.43 \pm 0.051$ (4)

$0.17 \pm 0.015$ (4)

$0.20 \pm 0.007$ (4)

$0.19 \pm 0.016$ (4)

$0.21 \pm 0.002$ (4) 
not accompanied by inhibition of histone F1 biosynthesis.

\section{Cyclic AMP changes in regenerating liver and the effect of adrenergic blocking agents}

It has been suggested that changes in the cyclic AMP concentration may have a controlling effect in early regeneration (MacManus et al., 1972, 1973; Gaza et al., 1973). The concentrations of cyclic AMP in our partially hepatectomized rats (Fig. 3) confirmed that there were increases in the cyclic AMP concentrations at $3-4 \mathrm{~h}$ and at $13 \mathrm{~h}$ after partial hepatectomy (MacManus et al., 1972, 1973), and indicated the existence of a third wave beginning at about $18 \mathrm{~h}$ and peaking at $21 \mathrm{~h}$, coincident with the period of DNA synthesis. The greater size of the first wave of cyclic AMP in our rats, compared with the results of MacManus et al. $(1972,1973)$, probably reflects differences in the strain used and also in the lighting and feeding schedule applied. Changes in ornithine decarboxylase activity during the first $24 \mathrm{~h}$ of regeneration (Fig. 4) showed similar differences from other published data (Hölttä \& Jänne, 1972; Gaza et al., 1973), with a large peak at $4 \mathrm{~h}$ and smaller ones at $11-12 \mathrm{~h}$ and $21 \mathrm{~h}$.

The three waves of cyclic AMP are initiated at the time of sensitivity to the $\alpha$-adrenergic blocking drugs (Fig. 1), i.e. at about $1.5,12-13$ and $17-18 \mathrm{~h}$ after partial hepatectomy, as are the first and third waves of ornithine decarboxylase. The second wave of enzyme induction at $10-12 \mathrm{~h}$ did not correspond to any point of sensitivity to the blocking agents.

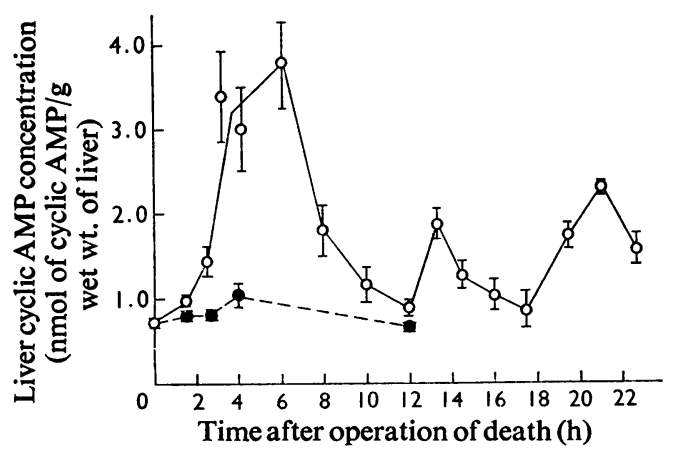

Fig. 3. Cyclic AMP concentrations in livers of rats after partial hepatectomy

Cyclic AMP concentration was measured as described in the Materials and Methods section and is expressed in nmol of cyclic AMP/g wet wt. of liver. Groups of five to ten rats were used for each time-point. $O$, Partially hepatectomized rats; $\bigcirc$, sham-operated rats.
In adrenalectomized, partially hepatectomized rats, the first wave of cyclic AMP was greatly diminished (Table 2). The $\beta$-adrenergic blocking agents, propranolol and pindolol, given at the time of operation, also inhibited the first wave of cyclic AMP (Table 2). This, with the results of MacManus et al. (1973), strongly suggests that catecholamines rather than glucagon are responsible for the first rise in cyclic AMP concentration after partial hepatectomy. The second wave of cyclic AMP synthesis, at $13 \mathrm{~h}$, was also inhibited by pindolol, suggesting that this wave too is due to catecholamines (Table 2). Neither actinomycin D $(35 \mu \mathrm{g} / \mathrm{kg})$ nor phenoxybenzamine $(5 \mathrm{mg} / \mathrm{kg})$ had an inhibitory effect on either of the first two waves of cyclic AMP synthesis (Table 2), indicating that the inhibition of ornithine decarboxylase induction by $\alpha$-adrenergic blocking agents (Thrower et al., 1973 and below) and of DNA synthesis by $\alpha$-adrenergic blocking drugs and actinomycin $D$ (Fig. 1) is not consequential on an inhibition of cyclic AMP production.

Phenoxybenzamine apparently increased the concentrations of cyclic AMP at 3 and $13 \mathrm{~h}$ in livers of partially hepatectomized rats. Rat liver behaves anomalously with respect to its $\alpha$ - and $\beta$-adrenergic receptors, and Exton et al. (1971) have data indicating that in this organ in the rat noradrenaline may stimulate adenylate cyclase. When the rats were reserpinized to deplete catecholamine concentrations, the effect of partial hepatectomy on liver cyclic AMP production at $3 \mathrm{~h}$ was decreased (Table 2), and phenoxybenzamine no longer enhanced the response of partially hepatectomized rats.

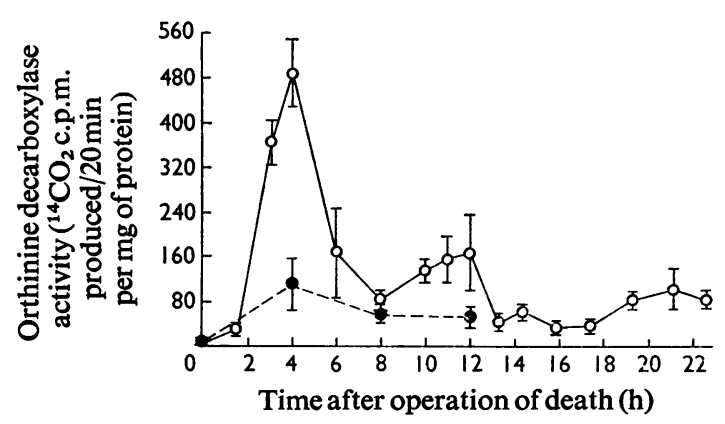

Fig. 4. Changes in ornithine decarboxylase activity during liver regeneration

Enzyme activity was measured as described in the Materials and Methods section. Ornithine decarboxylase activity is expressed as ${ }^{14} \mathrm{CO}_{2}$ c.p.m. produced/20 min per $\mathrm{mg}$ of protein. Groups of five to ten rats were used for each time-point. $O$, Partially hepatectomized rats; $\bigcirc$, shamoperated rats. 
Table 2. Cyclic AMP concentrations in livers of partially hepatectomized rats: the effects of adrenalectomy, adrenergic blocking agents, treatment with reserpine and actinomycin $D$

Rats were adrenalectomized 4 days before use. Reserpinized rats were given $1 \mathrm{mg}$ of reserpine/ $\mathrm{kg}$ at 72,48 and $24 \mathrm{~h}$ before operation. All drugs were given intraperitoneally. The doses were: actinomycin $\mathrm{D}, 35 \mu \mathrm{g} / \mathrm{kg}$ body wt.; phenoxybenzamine, $5 \mathrm{mg} / \mathrm{kg}$; propranolol, $10 \mathrm{mg} / \mathrm{kg}$; pindolol, (1) $0.5 \mathrm{mg} / \mathrm{kg}$, (2) $1.0 \mathrm{mg} / \mathrm{kg}$. Cyclic AMP concentrations are expressed as $\mathrm{nmol}$ of cyclic AMP/g wet wt. of liver \pm S.E.M., with the numbers of animals in parentheses.

Time after operation $(\mathrm{h})$

Treatment
Sham-operated
Partial hepatectomy
Adrenalectomy+partial hepatectomy
+Phenoxybenzamine
Partial hepatectomy
Reserpinized partially hepatectomized
+Phenoxybenzamine
Partial hepatectomy
+Phenoxybenzamine
+Actinomycin D
+Propranolol
Partial hepatectomy
+Pindolol (1)
+Pindolol (2)
Partial hepatectomy
+Phenoxybenzamine
+Pindolol (2)
Partial hepatectomy
+Actinomycin D

\begin{tabular}{cc}
\hline Treatment & Death \\
- & 4 \\
- & 4 \\
-0.5 & 4 \\
- & 4 \\
- & 3 \\
-0.5 & 3 \\
- & 3 \\
-0.5 & 2.5 \\
-0.5 & 2.5 \\
-0.5 & 2.5 \\
- & 2.5 \\
+1.0 & 3 \\
+1.2 & 3 \\
- & 3 \\
+10 & 13 \\
+12 & 13 \\
- & 13 \\
+10.5 & 12.8 \\
\hline
\end{tabular}

Cyclic AMP concentration

$1.04 \pm 0.13(4)$
$2.94 \pm 0.56(4)$
$1.65 \pm 0.08(3)$
$2.97 \pm 0.51(3)$
$3.37 \pm 0.53(5)$
$1.90 \pm 0.65(4)$
$1.05 \pm 0.30(3)$
$1.83 \pm 0.29(11)$
$3.26 \pm 0.79(5)$
$2.52 \pm 0.41(6)$
$0.85 \pm 0.33(4)$
$3.47 \pm 0.51(9)$
$2.58 \pm 0.29(6)$
$1.96 \pm 0.28(5)$
$2.01 \pm 0.17(9)$
$2.58 \pm 0.31(4)$
$1.54 \pm 0.08(4)$
$1.68 \pm 0.42(4)$
$1.62 \pm 0.31(4)$

Effects of adrenergic blockers on the induction of ornithine decarboxylase in normal and regenerating livers

The induction of ornithine decarboxylase is another early event in liver regeneration (Russell \& Snyder, 1968; Jänne \& Raina, 1968). Phenoxybenzamine $(5 \mathrm{mg} / \mathrm{kg})$ given just before partial hepatectomy delays the induction of the enzyme (Thrower \& Ord, 1972), which begins at $1.5 \mathrm{~h}$ after operation (Fig. 4). If the administration of the drug was delayed until $1 \mathrm{~h}$ after partial hepatectomy its inhibitory effects were still evident (Table 3), but by $2 \mathrm{~h}$ it had little effect on the amount of enzyme at $4 \mathrm{~h}$. The more selective $\alpha$ blocking agent, phentolamine, behaved similarly (Table 3). Propranolol and pindolol, at doses which decreased the first wave of cyclic AMP synthesis (Table 2), did not decrease the activity of ornithine decarboxylase (Table 3), indicating that elevated concentrations of cyclic AMP were not obligatory for the induction process.

The amount of ornithine used in the assay (Russell \& Snyder, 1968) gives concentrations below saturation for ornithine decarboxylase, but if $2 \mathrm{mM}$-L-ornithine is used, which is about ten times $K_{m}$ (Raina \& Jänne, 1968) the effect of partial hepatectomy is unchanged (Hölttä \& Jänne, 1972). The intracellular concentration of ornithine in the liver is increased 2-3-fold by $1 \mathrm{~h}$ after partial hepatectomy (Ord \&
Stocken, 1972b). This rise in the amount of unlabelled ornithine added to an assay system will affect the apparent increase in ornithine decarboxylase concentrations after partial hepatectomy reported here. Phenoxybenzamine does not affect (G. Hughes, personal communication) the entry of $\alpha$-aminoisobutyric acid into livers $1 \mathrm{~h}$ after partial hepatectomy nor the increase (I. Lieberman, personal communication) in $\alpha$-aminoisobutyric acid entry detectable by $3 \mathrm{~h}$ after operation. Uptake of $\left[{ }^{3} \mathrm{H}\right]$ lysine into total liver proteins (Table $1 b$ ) was also unaffected by phenoxybenzamine, suggesting that the drug affected neither the uptake of amino acids into the liver nor the intracellular amino acid pool. The decreased ornithine decarboxylase activity after phenoxybenzamine administration is therefore unlikely to be due to alterations in intracellular ornithine concentrations.

In adrenalectomized, partially hepatectomized rats, amounts of ornithine decarboxylase at 4 and $6 \mathrm{~h}$ were very low (Table 3), so that induction of the enzyme in regenerating livers did not seem to be significantly promoted by glucagon in the absence of glucocorticoids. Glucagon can be used to induce ornithine decarboxylase in intact livers (Panko \& Kenney, 1971); if phenoxybenzamine was given $0.5 \mathrm{~h}$ before the hormone, at doses three times those used in the partially hepatectomized rats, the drug had no effect on the induction process (Table 4). Similarly 
Table 3. Inhibition of ornithine decarboxylase induction after partial hepatectomy

Reserpinized rats received three doses of $1 \mathrm{mg}$ of reserpine/ $\mathrm{kg}$ at 72,48 and $24 \mathrm{~h}$ before operation. Other drugs were given intraperitoneally as shown. Ornithine decarboxylase was assayed as described in the Materials and Methods section. Ornithine decarboxylase activity is expressed as ${ }^{14} \mathrm{CO}_{2}$ c.p.m. released/20 min per $\mathrm{mg}$ of protein \pm s.E.M. The number of rats used for each value is given in parentheses.

\begin{tabular}{|c|c|c|c|c|}
\hline Treatment & $\begin{array}{c}\text { Dose } \\
\text { (mg/kg } \\
\text { body wt.) }\end{array}$ & $\begin{array}{l}\text { Time of } \\
\text { administration } \\
\text { (h after partial } \\
\text { hepatectomy) }\end{array}$ & $\begin{array}{l}\text { Time of death } \\
\text { after partial } \\
\text { hepatectomy (h) }\end{array}$ & $\begin{array}{l}\text { Ornithine decarboxylase } \\
\text { activity }\end{array}$ \\
\hline Sham-operated & - & - & 4 & $32.4 \pm 3.2(3)$ \\
\hline Partial hepatectomy & - & - & 4 & $157.8 \pm 16.8(9)$ \\
\hline +Phenoxybenzamine & 5 & -0.5 & 4 & $47.0 \pm 7.2(5)$ \\
\hline +Phenoxybenzamine & 5 & +1.0 & 4 & $39.6 \pm 9.0(7)$ \\
\hline +Phenoxybenzamine & 5 & +2.0 & 4 & $118.0 \pm 8.4(3)$ \\
\hline +Phentolamine & 10 & -0.5 & 4 & $80.6 \pm 16.8(3)$ \\
\hline +Phentolamine & 5 & +1.2 & 4 & $78.4 \pm 23.8(5)$ \\
\hline Partial hepatectomy & - & - & 3.2 & $161.4 \pm 14.8(13)$ \\
\hline$+17 \alpha$-Hydroxyprogesterone & 20 & -0.5 & 3.2 & $70.6 \pm 11.6(3)$ \\
\hline$+17 \alpha$-Hydroxyprogesterone & $2 \times 10$ & $+1.0,+1.7$ & 3.2 & $75.0 \pm 10.4(4)$ \\
\hline +Noradrenaline & $2 \times 0.5$ & $-0.5,+1.0$ & 3.2 & $309.8 \pm 34.0$ (4) \\
\hline +Propranolol & 10 & -0.5 & 3.2 & $183.2 \pm 37.0(5)$ \\
\hline +Actinomycin D & 0.035 & -0.5 & 3.2 & $242.0 \pm 50.0(5)$ \\
\hline Partial hepatectomy & - & - & 3 & $335.0 \pm 58.2(4)$ \\
\hline +Pindolol & 0.5 & +1.0 & 3 & $467.4 \pm 93.4(6)$ \\
\hline Partial hepatectomy & - & - & 3 & $362.0 \pm 38.0(4)$ \\
\hline Reserpinized & $3 \times 1$ & - & 3 & $130.0 \pm 43.2(4)$ \\
\hline $\begin{array}{l}\text { Reserpinized }+ \\
\text { phenoxybenzamine }\end{array}$ & 5 & -0.5 & 3 & $104.2 \pm 9.4(3)$ \\
\hline Partial hepatectomy & - & - & 4 & $595.0 \pm 69.2(4)$ \\
\hline Partial hepatectomy & - & - & 6 & $265.9 \pm 79.4(4)$ \\
\hline Adrenalectomized & - & - & 4 & $58.2 \pm 26.2(3)$ \\
\hline Adrenalectomized & - & - & 6 & $38.8 \pm 14.4(3)$ \\
\hline
\end{tabular}

Table 4. Effect of $\alpha$-adrenergic blocking agents and 17 1 -hydroxyprogesterone on hormonal induction of ornithine decarboxylase in normal rats

Single doses of hormone were injected intraperitoneally: glucagon $3 \mathrm{mg} / \mathrm{kg}$; growth hormone $0.4 \mathrm{mg} / \mathrm{kg}$; dexamethasone (1) $0.1 \mathrm{mg} / \mathrm{kg}$, (2) $0.5 \mathrm{mg} / \mathrm{kg}$. All inhibitors were given intraperitoneally $30 \mathrm{~min}$ before the administration of the hormone except (3), when two doses of $25 \mathrm{mg}$ of $17 \alpha$-hydroxyprogesterone $/ \mathrm{kg}$ were given, at $-0.5 \mathrm{~h}$ and at $1.0 \mathrm{~h}$. Ornithine decarboxylase activity was assayed as described in the Materials and Methods section; its activity is expressed as ${ }^{14} \mathrm{CO}_{2}$ c.p.m. released/ $20 \mathrm{~min}$ per $\mathrm{mg}$ of protein, \pm S.E.M. The number of rats used for each point is given in parentheses.

\begin{tabular}{lcr}
\multicolumn{1}{c}{ Treatment } & $\begin{array}{c}\text { Time of death } \\
\text { after operation }(\mathrm{h})\end{array}$ & $\begin{array}{c}\text { Ornithine decarboxylase } \\
\text { activity }\end{array}$ \\
0.9\% NaCl & 2.6 & $12.4 \pm 1.2(9)$ \\
Phenoxybenzamine $(5 \mathrm{mg} / \mathrm{kg})$ & 2.6 & $17.8 \pm 3.8(5)$ \\
Glucagon & 2.7 & $142.8 \pm 53.8(5)$ \\
+Phenoxybenzamine $(15 \mathrm{mg} / \mathrm{kg})$ & 2.7 & $138.6 \pm 36.4(5)$ \\
Growth hormone & 3.1 & $44.0 \pm 4.6(4)$ \\
+Phenoxybenzamine $(15 \mathrm{mg} / \mathrm{kg})$ & 3.1 & $50.4 \pm 16.0(4)$ \\
Dexamethasone $(1)$ & 2.6 & $178.2 \pm 22.8(4)$ \\
+Phenoxybenzamine $(15 \mathrm{mg} / \mathrm{kg})$ & 2.6 & $71.8 \pm 19.2(8)$ \\
Dexamethasone $(2)$ & 2.6 & $404.4 \pm 64.8(8)$ \\
+Phenoxybenzamine $(10 \mathrm{mg} / \mathrm{kg})$ & 2.6 & $283.6 \pm 84.8(4)$ \\
+Phentolamine $(30 \mathrm{mg} / \mathrm{kg})$ & 2.6 & $189.0 \pm 49.8(4)$ \\
Dexamethasone $(2)$ & 2.6 & $62.0 \pm 109.4(4)$ \\
+17 $\alpha$-Hydroxyprogesterone $(1 \times 50 \mathrm{mg} / \mathrm{kg})$ & 2.6 & $422.0 \pm 37.6(4)$ \\
+17 $\alpha$-Hydroxyprogesterone $(2 \times 25 \mathrm{mg} / \mathrm{kg})(3)$ & 2.6 & $280.4 \pm 61.6(4)$
\end{tabular}

Vol. 144 
it did not affect (Table 4) the induction of ornithine decarboxylase by growth hormone (Russell \& Snyder, 1969).

Reserpinized partially hepatectomized rats showed a lower induction of enzyme (Table 3) than normal partially hepatectomized rats; conversely, noradrenaline administration caused a twofold increase in the amount of ornithine decarboxylase present $4 \mathrm{~h}$ after partial hepatectomy (Table 3).

Glucocorticoids can also induce ornithine decarboxylase (Panko \& Kenney, 1971). The induction produced by dexamethasone was markedly decreased by phenoxybenzamine and phentolamine (Table 4).

$17 \alpha$-Hydroxyprogesterone has been shown to block cortisol and dexamethasone binding to steroidreceptor sites in rat liver (Baxter \& Tomkins, 1970). In normal rats $17 \alpha$-hydroxyprogesterone inhibited dexamethasone induction of ornithine decarboxylase (Table 4); the drug also inhibited ornithine decarboxylase induction after partial hepatectomy (Table 3). This evidence strongly implicates glucocorticoids in the induction of ornithine decarboxylase in liver regeneration.

\section{Discussion}

Hormones from the anterior pituitary or adrenals are not obligatory for the compensatory hyperplasia of partially hepatectomized rats (Harkness, 1957), but in their absence the process of regeneration is delayed. The experiments presented here suggest that catecholamines are promoting the activation of adenylate cyclase 2-4h after operation, and that glucocorticoids and possibly noradrenaline are affecting the induction of ornithine decarboxylase at the same time. Glucagon does not appear to be involved in either process.

Both cyclic AMP and glucocorticoids induce ornithine decarboxylase in normal rats (Beck et al., 1972), but their mechanisms of action are unknown, although Fausto (1971) has shown that in adrenalectomized rats amino acids or their metabolites can promote ornithine decarboxylase induction.

Our results show that in partially hepatectomized rats ornithine decarboxylase is still induced when adenylate cyclase stimulation has been prevented by propranolol or pindolol. Conversely, enzyme induction is prevented by $\alpha$-adrenergic blocking agents at doses which do not affect cyclic AMP concentrations. These data taken together strongly suggest that cyclic AMP is not obligatorily required in the early induction of ornithine decarboxylase.

MacManus et al. (1973) have shown that the first wave of cyclic AMP production after partial hepatectomy is not essential for DNA synthesis. With $30 \mathrm{mg}$ of phenoxybenzamine $/ \mathrm{kg}$ or $30 \mathrm{mg}$ of DLpropranolol $/ \mathrm{kg}$ given at $8 \mathrm{~h}$ after partial hepatectomy they obtained a delay in the second peak of cyclic AMP, and in DNA synthesis. From this they con- cluded that this wave of cyclic AMP was essential for DNA synthesis to take place. With the smaller doses of phenoxybenzamine used here, although DNA synthesis was still inhibited, the second wave of cyclic AMP synthesis was unchanged. Conversely, $1.0 \mathrm{mg}$ of pindolol $/ \mathrm{kg}$ at $12 \mathrm{~h}$ inhibited the rise in cyclic AMP concentrations at $13 \mathrm{~h}$ (Table 2), without affecting DNA synthesis, and even with doses of up to $5 \mathrm{mg} / \mathrm{kg}$, DNA synthesis at $22 \mathrm{~h}$ was unaffected [thymidine uptake into DNA of untreated partially hepatectomized rats $6.9 \pm 0.5(5)$; partially hepatectomized rats given $5 \mathrm{mg}$ of pindolol $/ \mathrm{kg}$ at $11.5 \mathrm{~h}$, $6.9 \pm 0.8(6)]$. It thus seems that neither of the two early peaks in cyclic AMP concentrations is essential for DNA synthesis after partial hepatectomy.

Whatever their function, however, the peaks in cyclic AMP production coincide with periods of sensitivity of the regenerative process to $\alpha$-adrenergic blocking drugs, and with the initiation of waves of enzyme induction (see Bucher \& Malt, 1971 ; Bresnick, 1971). Ornithine decarboxylase increases coincidentally with the first wave of cyclic AMP; the second cyclic AMP wave at $12-13 \mathrm{~h}$ is at the time when signals are given for induction of enzymes necessary for DNA replication. At the time of the third wave, DNA synthesis and the synthesis of enzymes involved in replication are accelerating sharply (Fig. 2). The importance of these periods of protein synthesis is underlined by the effects of single low doses of actinomycin D on the peak of DNA synthesis. This is delayed by actinomycin given up to $7 \mathrm{~h}$ after operation, or at $10.5 \mathrm{~h}$, or between 15 and $17 \mathrm{~h}$, indicating that RNA synthesis is essential at these times.

The sites for $\alpha$-adrenergic blocking agents and the mechanism of action of noradrenaline on rat liver are uncertain, as is the relation between the effects of noradrenaline and glucocorticoids. Exton et al. (1972) have discussed the role of glucocorticoids in liver in maintaining responsiveness to cyclic AMP. The sensitivity of liver regeneration to phenoxybenzamine, phentolamine and $17 \alpha$-hydroxyprogesterone suggests that in rats noradrenaline and glucocorticoids may be implicated in the inducible protein synthesis after operation, but the factors leading to the periodicity in cyclic AMP concentrations and in protein induction are not yet understood. The greater sensitivity of inducible rather than endogenous protein synthesis to the actions of the $\alpha$-adrenergic blockers parallels the effects of ionizing radiation (Van Lancker, 1970) on liver regeneration.

We thank the Cancer Research Campaign for financial support, and S. T. is grateful to the Wellcome Trust for a Research Training Scholarship.

\section{References}

Baxter, J. D. \& Tomkins, G. M. (1970) Proc. Nat. Acad. Sci. U.S. 65, 709-715 
Beck, W. T., Bellantone, R. A. \& Canellakis, E. S. (1972) Biochem. Biophys. Res. Commun. 48, 1649-1654

Bresnick, E. (1971) in Methods in Cancer Research (Busch, H., ed.), vol. 6, pp. 347-397, Academic Press, London and New York

Bucher, N. L. R. \& Malt, R. A. (1971) Regeneration of Liver and Kidney, New England Journal of Medicine Medical Progress Series, Little, Brown and Co., Boston Burton, K. (1956) Biochem. J. 62, 315-323

Cooper, R. H., McPherson, M. \& Schofield, J. G. (1972) Biochem. J. 127, 143-154

Dabeva, M. D. \& Tsanev, R. G. (1966) Anal. Biochem. 17, 390-396

Exton, J. H., Robison, G. A., Sutherland, E. W. \& Park, C. R. (1971) J. Biol. Chem. 246, 6166-6177

Exton, J. H., Friedmann, N., Wong, E. H.-A., Brineaux, J. P., Corbin, J. D. \& Park, C. R. (1972) J. Biol. Chem. 247, 3579-3588

Fausto, N. (1971) Biochim. Biophys. Acta 238, 116128

Fujioka, M., Koga, M. \& Lieberman, I. (1963) J. Biol. Chem. 238, 3401-3406

Furchgott, R. F. (1972) in Handbook of Experimental Pharmacology (Blaschko, H. \& Muscholl, E., eds.), vol. 23, pp. 283-335, Springer-Verlag, Berlin

Gaza, D. J., Short, J. \& Lieberman, I. (1973) Biochem. Biophys. Res. Commun. 54, 1483-1488

Harkness, R. D. (1957) Brit. Med. Bull. 13, 87-93

Higgins, G. M. \& Anderson, R. M. (1931) Arch. Pathol. 12, 186-202

Hölttä, E. \& Jänne, J. (1972) FEBS Lett. 23, 117-121
Hopkins, H. A., Bonney, R. J., Walker, P. R., Yager, J. D. \& Potter, V. R. (1973) Advan. Enzyme Regul. 11, 169191

Jänne, J. \& Raina, A. (1968) Acta Chem. Scand. 22, 1349_ 1351

Lowry, O. H., Rosebrough, N. J., Farr, A. L. \& Randall, R. J. (1951) J. Biol. Chem. 193, 265-275

MacManus, J. P., Franks, D. J., Youdale, T. \& Braceland, B. M. (1972) Biochem. Biophys. Res. Commun. 49, 12011207

MacManus, J. P., Braceland, B. M., Youdale, T. \& Whitfield, J. F. (1973) J. Cell. Physiol. 82, 157-164

Ord, M. G. \& Stocken, L. A. (1972a) FEBS Symp. 24, $165-167$

Ord, M. G. \& Stocken, L. A. (1972b) Biochem. J. 129, 175-181

Ord, M. G. \& Stocken, L. A. (1974) in Liver Regeneration after Experimental Injury, in the press

Panko, W. B. \& Kenney, F. T. (1971) Biochem. Biophys. Res. Commun. 43, 346-350

Raina, A. \& Jänne, J. (1968) Acta Chem. Scand. 22, 23752378

Russell, D. H. \& Snyder, S. H. (1968) Proc. Nat. Acad. Sci. U.S. 60, 1420-1427

Russell, D. H. \& Snyder, S. H. (1969) Endocrinology 84, 223-228

Thrower, S. \& Ord, M. G. (1972) Biochem. J. 130, 9P-10P

Thrower, S., Ord, M. G. \& Stocken, L. A. (1973) Biochem. Pharmacol. 22, 95-100

Van Lancker, J. L. (1970) Fed. Proc. Fed. Amer. Soc. Exp. Biol. 29, 1439-1442 